Guest Editorial, part of a Special Feature on Sustainable Land-Use Practices in Mountain Regions: Integrative Analysis of Ecosystem Dynamics Under Global Change, Social-Economic Impacts, and Policy Implications

\title{
Sustainable Land-use Practices in European Mountain Regions under Global Change: an Integrated Research Approach
}

\author{
$\underline{\text { Robert Huber }}^{1}, \underline{\text { Harald Bugmann }}^{2}$, Alexandre Buttler $^{1,3}$ and Andreas Rigling $^{1}$
}

\begin{abstract}
This Special Feature on sustainable land-use practices in European mountain regions presents results from the inter- and transdisciplinary research project MOUNTLAND. The goal was to investigate the sensitivity of the provision of ecosystem services to both climatic and land-use changes and to suggest alternative policies and governance structures for mitigating the impact of such changes and enhancing sustainable management practices in mountain regions. The individual articles provide: (1) new scientific findings regarding the impacts of climate and land-use changes on ecosystem processes in three sensitive mountain regions of Switzerland; (2) an assessment of the feedback effects arising from changing socioeconomic and political conditions, land use, and adaptation to climate change, using modeling techniques and transdisciplinary stakeholder interactions; and (3) suggestions for alternative policy solutions to ensure sustainable land use in mountain regions. In our synthesis of the project, we provide insights from the ecological, socioeconomic, and political sciences in the context of humanenvironment interactions in mountain regions. The innovation of this Special Feature lies in the fact that all articles present truly inter- or transdisciplinary research, ranging from natural sciences to economics and political sciences, based on an overarching set of unifying research questions.
\end{abstract}

Key Words: adaptation; climate change; ecosystem services; experiments; interdisciplinary research; land-use change; management; modeling; transdisciplinary research

\section{INTRODUCTION}

Mountain ecosystems provide a variety of important goods and services for humans such as food, timber, fresh water, protection from natural hazards, carbon storage, and a range of immaterial functions for recreation and tourism (Messerli and Ives 1997). These ecosystems, however, are highly sensitive to both climatic and land-use changes (Huber et al. 2005, Bugmann et al. 2007). Consequently, the provision of ecosystem goods and services (EGS) is very likely to change in the future (Schröter et al. 2005, Carpenter et al. 2006, Gonzalez et al. 2010).

For people living in European mountain regions, key challenges arising from changes in land use and climate include the marginalization of economic activities such as agricultural and timber production (Gotsch et al. 2004, Soliva 2007, Streifeneder et al. 2007, Flury et al. 2013), increasing water conflicts (Beniston 2012), changes in the protection value of forests (Grêt-Regamey et al. 2008), and landscape degradation due to land abandonment or land-use intensification and corresponding loss of biodiversity (MacDonald et al. 2000, Zimmermann et al. 2010). These developments tend to be accompanied by the emigration of economically active segments of society and the aging of the local population (Messerli et al. 2011). The expected anthropogenic climate change will accentuate these problems by changing disturbance regimes, increasing drought conditions, and negatively affecting the development of at least some ecosystems in mountain regions. Viewed historically, there has been a trend toward increasingly specialized land-use policies; over the years, this has led to an ongoing increase in sectoral regulations (Balsiger 2009). This has caused more overlap and sometimes even conflicts and contradictions between policies and regulations at different scales (Cash et al. 2006). Consequently, the implementation of sustainability policies has remained challenging, and there is still much to be done (Kok and Veldkamp 2011).

Alternative and congruent land-use management strategies and policies must be identified to meet these challenges. They should support both the provision of EGS and the economic viability of the regions (Groot et al. 2010). Moreover, the political system, with its institutions, policies, and administrative structures, plays a crucial role in mitigating and adapting to the impacts of climate change on ecosystem and landscape dynamics in mountain regions (Beniston 2003). Thus, management and policy alternatives that support the provision of EGS in these regions should not only be economically and ecologically efficient, but also institutionally feasible and socially acceptable.

In addition, climate change, ecosystems and their dynamics, socioeconomics, and politics are interlinked in a system with multiple feedbacks. It is impossible to predict a priori the overall effects of changes in any of the system's components. Indeed, the analysis of the impacts of climate and land-use change on the provision of EGS in mountain regions requires a complex systems approach in which both human and environmental dynamics are studied over a range of spatial 
and temporal scales. Only integrated, multi-disciplinary research, in combination with dedicated disciplinary research on individual processes and mechanisms, can provide the kind of information needed to understand complex systems and to address interlinked environmental and social problems (Carpenter et al. 2009).

There is an emerging tradition of research on human-nature interactions, and various approaches addressing the complexity of such systems have been proposed (Alberti et al. 2011, Scholz and Brand 2011). Such approaches include, for instance, hierarchies and adaptive cycles for sustainable development (Holling 2001), resilience research (Folke 2006), studies of interactions between ecosystems and their impacts on human well-being (Millennium Ecosystem Assessment 2005), frameworks for the analysis of social-ecological systems (Ostrom 2009), and analyses coupling human and natural systems (Liu et al. 2007, Alberti et al. 2011). Most recently, Scholz (2011) presented a framework for the analysis of human-environmental systems that can be used as a blueprint for inter- and transdisciplinary environmental studies. Irrespective of the value of the specific framework, inter- and transdisciplinary research is generally seen as the key to overcoming fundamental problems in the analysis of such complex systems (Millennium Ecosystem Assessment 2005, Liu et al. 2007, Carpenter et al. 2009, Ostrom 2009). Here, we provide a brief overview of a research project called Mountland, in which such an approach was adopted. We focus on ecosystem goods and services under climate and land-use changes in three mountain case study areas.

\section{CONCEPTUAL BACKGROUND AND RESEARCH QUESTIONS}

An integrative approach was applied in MOUNTLAND, combining methods from economics and the political and natural sciences to analyze ecosystem functioning and management in mountain regions under climatic and socioeconomic change. The various disciplines collaborated from the very outset to achieve a holistic humanenvironmental perspective. Thus, our research did not involve a cascade of different research findings, but explicitly considered feedback effects from changing socioeconomic and political conditions on land use and adaptation to climate. This represents a major challenge in interdisciplinary research (Steffen 2009, Müller et al. 2010). The collaboration among the different research disciplines was based on four pillars.

1. A common set of research questions guaranteed a consistent focus in the different case study regions. The guiding research questions were:

- What is the effect of a changing climate (temperature and precipitation) on sensitive ecosystem processes and their spatial interactions, which in turn affect the ability of mountain ecosystems to provide crucial EGS such as protection against natural hazards and production of food and timber?

- What are the effects of climate-, socioeconomic-, and policy-driven changes in land use on EGS provided by mountain landscapes?

- What existing sectoral and cross-sectoral policies and policy instruments have which effects on the provision of EGS in mountain regions? Which policy solutions could best mitigate negative climate effects and major socioeconomic changes in mountain regions and enhance sustainable land use in these regions?

2. Throughout the study, all analyses were based on a common set of scenarios. In these scenarios, the consequences of global change at climatic, market, and policy levels were downscaled consistently with the global Intergovernmental Panel of Climate Change Special Report on Emissions Scenarios to tally with our case study regions and then summarized in storylines (A. Walz, unpublished manuscript). This strongly improves the feasibility of a synthesis of the different research findings across regions (Eppink et al. 2012).

3. The linkage of ecological and socioeconomic models in the case study regions allowed for the quantification of feedback effects. These feedback effects were obtained using plot-based observational and experimental evidence explored in a modeling framework and upscaled to the landscape level. They also allowed for integration of alternative policy solutions and institutional reforms to mitigate the negative effects of climate change; thus, the feedback between ecological effects of climate change, land-use changes, and policy could be closed.

4. The methods chosen, e.g., formative scenario analysis to downscale scenarios or network analysis to describe the existing policy network, implied that effective and intensive collaboration with residents and local decision makers was essential. An institutionalized dialog with the stakeholders allowed our research to be anchored in the real world.

This approach resulted in truly inter- and transdisciplinary work. The added value of this approach was threefold: (1) data and models were based on biophysical realism; (2) local tradeoffs could be considered; and (3) comprehensive, critical involvement of stakeholders within the studies was achieved. These are important facets that characterize the holistic ideal of ecosystem services research, as concluded from a quantitative review of the recent literature on EGS by Seppelt et al. (2011). 
Fig. 1. Map of the European Alps and illustrative photographs of the three Mountland case study regions. Spatially explicit modeling focused on the core zones (opaque red). The circular areas (transparent red) indicate the areas of application, including the locations of some of the plot-scale experiments. Map produced by A. Psomonas, WSL. Photos: Alexandre Buttler and Andreas Rigling, WSL.

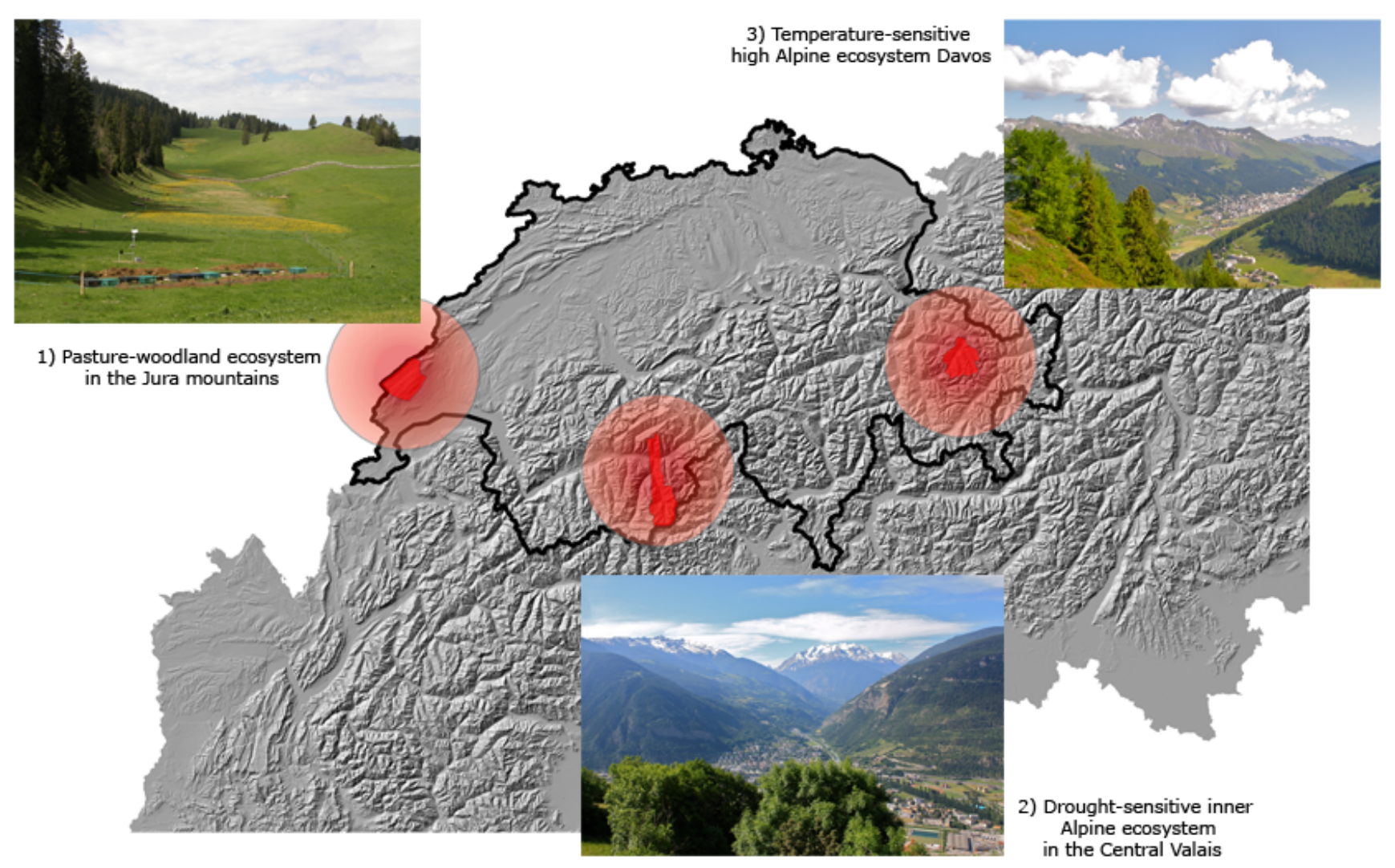

\section{STUDY REGIONS}

The three case study regions selected in the Swiss Alps are complementary rather than directly comparable (Fig. 1). In the case study region Jura, we focused on pasture-woodland ecosystems. The Central Valais region is representative of drought-sensitive inner alpine ecosystems. The high alpine ecosystems in Davos are temperature sensitive. The three regions differ in terms of their expected sensitivity to both climate and land-use changes, the relevance of particular EGS, and the significance of different sectoral and cross-sectoral policies, as explained next.

Pasture-woodland ecosystem: The Jura is an oceanic mountain area sensitive to land-use change and increases in temperature. The region is also a hotspot for biodiversity and has been chosen for many past and ongoing research projects in grassland, woodland, and wetland ecology (Buttler et al. 2009). The area is suitable for exploring questions regarding the dynamics of forests, wooded pastures, and grasslands, as well as the patterns of segregation/integration of land use and their interrelationships with disturbances arising from climate change. The case study region covers an area of $164 \mathrm{~km}^{2}$ and contains approximately 6000 inhabitants.

Drought-sensitive inner alpine ecosystem: The Central Valais is a drought-sensitive continental inner-alpine mountain area. It is suitable for studying the dynamics and diversity of mountain-protected forests and grasslands and their interrelationship with disturbances, in particular fire, insect, and pathogen damage brought about by climate change (Rigling et al. 2013). The study area covers $350 \mathrm{~km}^{2}$ and contains 15,000 inhabitants. Visp is a booming urban hotspot with industry and international traffic corridors. Saas Fee and Visperterminen are important destinations for summer and winter tourism. The Baltschieder Valley is a remote, uninhabited alpine side-valley with no infrastructure.

Temperature-sensitive high alpine ecosystem: The inneralpine high mountain area of Davos is sensitive to temperature changes. It is suitable for studying the dynamics and diversity 
of subalpine protected forests and grasslands as well as their relationships with the occurrence of natural hazards, in particular avalanches, rock falls, debris flows, erosion, and insect infestations associated with these types of damage (Grêt-Regamey et al. 2008). The study area includes the municipality of Davos and covers an area of $254 \mathrm{~km}^{2}$. The local population amounts to approximately 13,000 people and there are approximately 25,000 guest beds. The principal town, Davos, with its well-established urban and tourist infrastructure, is located in the central part of the main valley. The rest of the main valley and the three side valleys have remained relatively rural with a few small, scattered settlements and a landscape still strongly dominated by mountain agriculture.

\section{ECOSYSTEM SERVICES}

Unfortunately, there is no universally accepted typology of EGS (Haines-Young and Potschin 2009, Gómez-Baggethun et al. 2010, Braat and de Groot 2012). There is an ongoing debate dealing with the need to distinguish benefits from services and ecological functions, as well as intermediate vs. final services, to avoid the problem of double counting (Boyd and Banzhaf 2007, Wallace 2007, Costanza 2008, Fisher and Turner 2008, Haines-Young and Potschin 2009). Thus, it is likely that a pluralism of typologies will continue to exist, as each will be useful for a different purpose (Costanza 2008). Nevertheless, the definitions of EGS provided by the Millennium Ecosystem Assessment (2005) are still useful as a common basis (Haines-Young and Potschin 2009) and are widely applied (Seppelt et al. 2011).

The choice of EGS was based on their social and scientific relevance in the corresponding case study region. Food and timber production dominates land use in all case study regions; therefore, we focused on EGS related to land use because these are affected by changes in agricultural and forest management. Thus, the EGS covered include production of food and timber, protection against natural hazards, and provision of carbon cycle and habitat services (Table 1). Indicators were used to represent these EGS with a case-specific (optimal) degree of aggregation (Table 1; Müller and Burkhard 2012).

Agriculture has an intermediate position in the context of ecosystem services. It affects a wide range of supporting, regulating, and cultural ecosystem services, including water quality, nutrient cycling, carbon sequestration, and biodiversity conservation (Heal and Small 2002). In turn, ecosystem services influence agricultural productivity and thus the production of food (Dale and Polasky 2007). The same conclusion applies to timber production.

Protection from natural hazards is a prerequisite for life in mountain regions because it prevents damage to humans, buildings, and infrastructure from avalanches, landslides, or rock falls. Without the protective function of mountain forests, expensive artificial protection measures would be necessary (Brang 2001).

The provision of habitat services ensures the maintenance of biological diversity from the landscape to the genetics scale. Therefore, habitat services are the basis for most other functions and EGS (Groot et al.2010). Because mountain areas are storehouses of global biodiversity (Spehn et al. 2010), changes in the availability of different habitats also have implications that range beyond our case study regions.

Lastly, mountain landscapes provide climate regulation services. Specifically, forests currently act as net sinks of greenhouse gases in most temperate areas, and agriculture is currently a net source of greenhouse gases (Smith et al. 2008). Agriculture involves livestock husbandry and soil cultivation and is a major source of methane and nitrous oxide, which are major greenhouse gases.

\section{TRANSDISCIPLINARY ASPECTS}

We viewed the dialog with stakeholders as a crucial integrative activity. It was not set up as a separate task, but was included as a cross-sectional activity to provide guidance for the research process. The stakeholder dialog consisted of two strongly inter-linked phases.

In the first phase, a steering group representing the core stakeholders was set up in each study region. Each steering group consisted of six to nine representatives of the typical stakeholder groups who advised the project leaders from a study-region perspective. This sometimes included the specification of goals for certain research activities from the perspective of the final addressees at the implementation level. Furthermore, the steering group reviewed and discussed the preliminary results and coordinated the involvement of specific stakeholders in the different activities by selecting interview partners. In addition, these groups were important for disseminating information, particularly the scientific results in each region.

In the second phase, regional transition scenarios with extended stakeholder groups were developed using a functional-dynamic concept of stakeholder involvement. The insights gained in the different parts of the project served as the basis for these processes. Because of funding and time constraints, this second phase of the stakeholder involvement was only implemented in the Valais case study region (Brand et al. 2013).

\section{INTERDISCIPLINARY WORKFLOW}

The framework and the iterative procedure followed by the different research groups comprised seven steps (Fig. 2). The framework did not aim to cover every detail of the whole research done. It aimed to provide an overview and facilitate communication with other scientists (Alberti et al. 2011). 
Table 1. Ecosystem goods and services considered in the Mountland project.

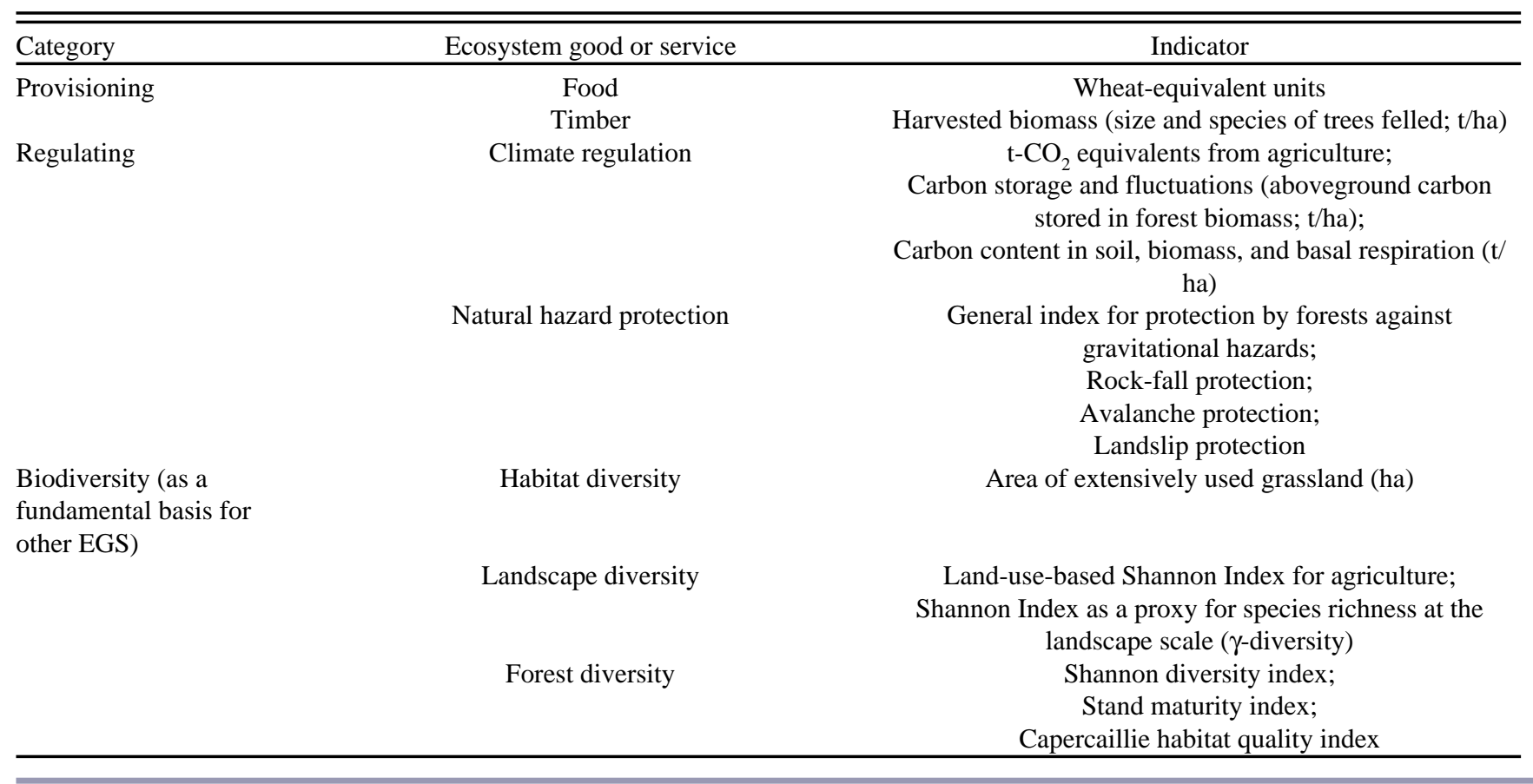

Step 1: The starting point was the formulation of context scenarios for the three case study regions based on the formative scenario approach by Scholz and Tietje (2002). In these scenarios, the consequences of global change at climate, market, and policy levels were downscaled to our case study regions and summarized in storylines (A. Walz, unpublished manuscript). These storylines provided the basis for a modelbased analysis of ecosystem development and land-use decision-making.

Step 2: The ecological research included field investigations, experiments, and modeling (Fig. 2, green boxes) involving two different research approaches. First, ecological field experiments yielded specific information about the effects of climate change on sensitive ecosystem processes in mountain regions. For example, high-altitude soil turf monoliths with their herbaceous vegetation were transplanted from Col du Marchairuz to lower altitudes to investigate the effects of different levels of climate warming and reduced precipitation intensities in interaction with different land-use practices typical for the Jura mountains (Gavazov et al. 2013). In Davos, data from a long-term experiment at the treeline on Stillberg were analyzed (Martin et al. 2010). In the case study region Valais, field studies and drought experiments investigated the germination, growth, and mortality of different tree species (Brunner et al. 2009, Eilmann et al. 2009, Dobbertin et al. 2010, Eilmann and Rigling 2012, Rigling et al. 2013). These experimental findings were used to improve existing mechanistic models (Schumacher et al. 2004, Lischke et al. 2006, Gillet 2008) in the corresponding area. Thus, interdisciplinary findings from natural scientists could be modeled and upscaled to the regional level to quantify changes in the EGS in a spatially explicit manner (Elkin et al. 2012, Peringer et al. 2013).

Step 3: The simulation results for ecosystem dynamics were used as input for the analysis of socioeconomic impacts (Fig. 2 , blue boxes). An economic land-use optimization model was constructed to represent competition between agricultural and forest land use in the different scenarios, thus providing information on changes in EGS in all three case study regions. The model results showed the trade-offs between economic gains from primary production and provision of EGS under various climate change scenarios in the different regions (Briner et al. 2013). The decision-making of local actors was analyzed using agent-based modeling techniques (Hirschi et al. 2013, Huber et al. 2013a). In addition, these models allowed information from the forest models to be integrated with the policy issues studied.

Step 4: The basis for these models was provided by the analysis of local decision-making. The agent-based models were rendered operational by means of local scenarios developed in close collaboration with residents and policy makers in the case study region (Brand et al. 2013), as well as surveys with the farmers living in the different regions.

Step 5: A combination of ecological and economic modeling approaches and the explicit inclusion of feedback effects facilitated an assessment of changes in EGS provisioning in the case study regions. EGS were quantified in a spatially 
Fig. 2. Workflow and research methods in the Mountland project. Green boxes refer to ecological research, blue to socioeconomic research, and orange to policy assessments. Numbers indicate iterative procedure steps.

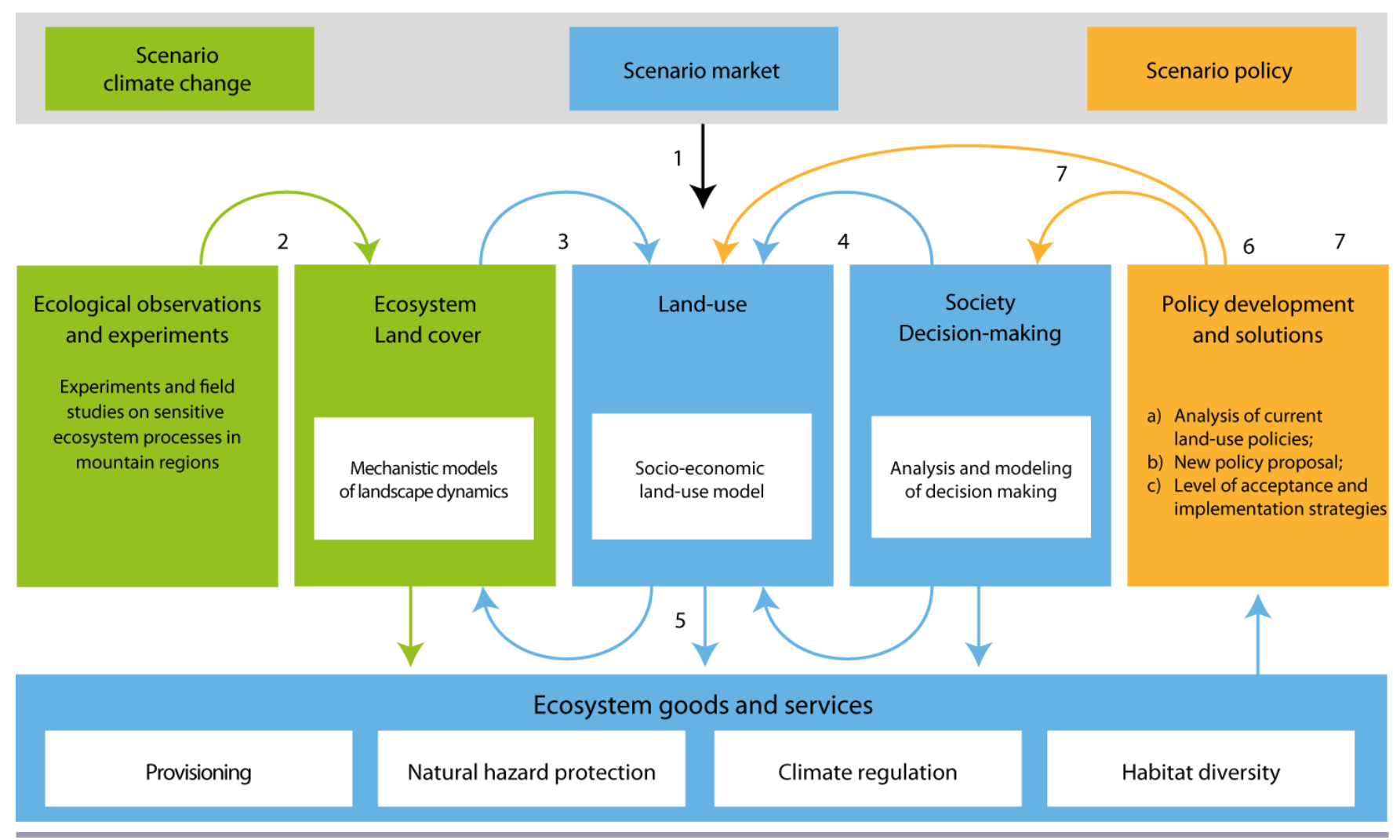

explicit manner based on simulated land-cover and land-use changes. The trade-offs between economic gains from primary production and provision of EGS under various climate change scenarios in the different regions were assessed (Briner et al. 2013, Huber et al. 2013a).

Step 6: To appraise the political aspects of the provision of mountain EGS (Fig. 2, orange boxes), network analysis (Hirschi 2010, Ingold et al. 2010, Hirschi et al. 2013) was used with focus on how different policies were implemented and what policy relevant indicators could be applied for the evaluation and valuation of the different ecosystem services. With respect to the latter, a policy-oriented indicator system for ecosystem services was developed. We referred to the goals formulated in specific policy programs (e.g., National Forest Program and Agricultural Reforms 2011 and 2014-2017), as well as established indicator systems (e.g., Switzerland's MONET indicators for sustainability assessment).

Step 7: The policy indicators were used to evaluate the different outcomes of the scenarios and to assess the acceptance of policies supporting the provision of EGS. If the modeling outcome deviated greatly from the normative state of the corresponding indicator, a policy change was proposed and fed back into the system of models using a new policy scenario. This procedure permitted the assessment of feedback effects between changes in policy, socioeconomics, and climate on the provision of EGS in the three case study regions.

\section{CONTENTS OF THIS SPECIAL FEATURE}

The content of this Special Feature is closely aligned with the interdisciplinary workflow described above. The different contributions cover a wide range of the ecosystem service framework from natural science to socioeconomic analysis and policy assessment (Fig. 2) under the umbrella of a common set of research questions. Moreover, all of the articles explicitly unite different research groups in an interdisciplinary setting and/or are based on transdisciplinary methods.

Gavazov et al. (2013) took soil turf monoliths with their herbaceous vegetation from three different habitats representing a land-use gradient and transplanted them at lower altitudes. The resulting experimental findings, linked with the landscape modeling of silvopastoral ecosystems, represent the interface of ecological experiments and modeling. The authors assessed the development of forage provision across the patterned landscape under future warming 
scenarios. To a certain degree, this approach overcomes the restricted predictive power of traditional approaches to vegetation modeling, which use calibration data exclusively from the past.

These findings were an important input for the investigation of wooded pasture dynamics conducted by Peringer et al. (2013). These authors apply an innovative combination of a retrospective analysis starting in the Middle Ages with a projective simulation study of different climate change scenarios. The historical analyses demonstrate the strong dependency of the landscape mosaic of wooded pastures on both climate and land-use intensity. The climate change scenarios indicate that structural changes in the landscape mosaic would, in general, be slow but inevitable, with a dramatic, medium-term breakdown in the ecosystem service of wood production, depending on the degree of climate warming.

The importance of historical aspects in the analysis of landscape changes in wooded pastures is also addressed by Chételat et al. (2013). These authors provide an analysis of land-use transitions in silvopastoral landscapes. They document changes in the intensity of land use in two wooded pastures in the Swiss Jura Mountains, combining quantitative approaches (aerial image analyses) with pastoral chronicles, and analyze those changes in light of changes in natural events such as storms and land-use policy. The results illustrate the interrelated effects of climate and socioeconomic driving forces on a highly sensitive ecosystem.

Huber et al. (2013a) provide a link between future alternative policy changes and the vegetation dynamics of wooded pastures using a simulation analysis that links vegetation dynamics models and agent-based land use with policy analysis. The effects of two different scenarios were analyzed and their effects on landscape dynamics assessed based on an iterative exchange of model results. The authors used a policy network analysis to assess the political feasibility of different policy measures addressing potential negative impacts on landscape dynamics in the different scenarios, and then fed the results back into the model chain. This allowed them to take into account not only ecological feedbacks, but also feedbacks from the policy-making process. Thus, this contribution links all the disciplines addressed in the interdisciplinary workflow of the MOUNTLAND project.

The feedback from the policy making process in Huber et al. (2013a) is based on the analysis of the interface between policy structures and scientific scenario analysis provided by Hirschi et al. (2013). These authors make a first attempt to combine different policy scenario analysis with policy network analysis in agricultural policy. They experiment with model outputs based on scenarios and on actual and potential policy network structures. This provides a valuable basis for policy makers and policy experts working on the design of future land-use policies under changing ecological, socioeconomic, and political conditions.

Another valuable input for the design of land-use policies is the representation of local trade-offs and synergies in ecosystem management. Briner et al. (2013) present an assessment of such trade-offs and synergies in the provision of different EGS under current and predicted climate and market conditions in the Valais case study. The modeling framework that they apply combines findings from agriculture- and forestry-simulated trade-offs between the spatially explicit provision of food, protection, carbon sequestration, and habitat services. The model chain used provides an important tool for linking land-cover and land-use change with changes in EGS.

Grêt-Regamey et al. (2013) present an integration of expert knowledge into EGS mapping. Insights from expert surveys were fed into a GIS-based Bayesian network for valuing EGS under different land-use and climate change scenarios. The authors accounted for uncertainties in land-use and climate change by mapping the risk of changes in the future EGS flow. The results document a novel approach for presenting the impact of climate and land-use changes to stakeholders and policy makers.

Spatially explicit information of this kind from the model chain was partly used in the transdisciplinary research approach in the Visp region. Brand et al. (2013) deal with the issue of how stakeholder involvement in Valais can contribute to a better understanding of the challenges facing mountain regions under global change and their linked future development. The authors present a set of consistent multi-scale scenarios that reflect the values, interests, and knowledge of local people in Valais, and expert knowledge on global and Swiss development. This article represents an important outcome of the transdisciplinary process.

Finally, the main conclusions of the different studies are presented by Huber et al. (2013b), who summarize the findings from the different disciplines and regions.

\section{DISCUSSION}

MOUNTLAND provides evidence for the successful implementation of inter- and transdisciplinary research in the context of EGS in mountain areas. As a result, locally adapted land-use practices and alternative policy solutions have been developed for both forest and grassland ecosystems in mountain regions. Although the definition of a common framework at the outset and the development of a model for the workflow to be shared across its entirety were laborious and time-consuming, they ensured that the different research groups could interact frequently and collaborate closely. The various studies were tightly interlinked, adding value to the individual studies. In addition, the development of context scenarios linking global change to national characteristics and 
subsequently to the specific case study regions allowed for a comprehensive comparison of the different case study regions and supported the view that the national (or even global) perspective and local land management are interdependent.

Our integrative approach added important findings on feedback effects and cross-scale interactions in mountain regions. Integrating biophysical components via the ecological models in the socioeconomic models, in particular, provided a spatially explicit basis for an in-depth analysis of EGS provision. Without this information on the ecological processes involved in service supply, it would have been quite difficult to quantify and map EGS (Claessens et al. 2009, Müller et al. 2010, Kragt et al. 2011, Maes et al. 2012).

One key challenge that was highlighted by the project is determining how to design appropriate policy and governance systems and then implement them in diverse biophysical and social contexts (Daily and Matson 2008). Here, existing governance structures within a specific dominant policy paradigm tend to prevent policy change in a given sector because they are perpetuated by established structures among influential actors. These structures tend to constrain the implementation of policies supporting EGS provision. This specific restriction was explored by using policy network analysis, which provides a valuable approach for analyzing such structures in the relevant sectors.

Another challenge facing integrative assessment of decisions influencing the provision of EGS is how to use and integrate data sources (Müller et al. 2010). Our modular modeling structure resulted in a chain of models, effectively all spatially explicit, which allowed for sound integration of the data. Moreover, regular group meetings and frequent face-to-face contact between the researchers helped to overcome some of the problems involved in data integration and to deal with some of the well-known constraints in inter- and transdisciplinary research such as limited resources with respect to time and funding and a lack of common terminology (Tress et al. 2001, 2005, 2007).

Values must be taken into account to bring ecosystem services into decision-making processes (Daily et al. 2009). Our project considered stakeholder perspectives and included various alternative scenarios for the future. These were based on a set of coupled models with maps, trade-off curves, and balance sheets, which are important when addressing bundles of EGS (Nelson et al. 2009, Braat and de Groot 2012). The collaboration with local stakeholders guaranteed a strong anchor in the real-world problems of the people living in the case study areas and improved the understanding and implementation of our field studies, experiments, and models. As a result, the stakeholders' preferences are reflected in the outcome of the project. Moreover, an integrative perspective allowed us to bring together stakeholders from different interest groups and political sectors and to discuss possible impacts of global change in a cross-sectoral setting. This is an important precondition if interlinked environmental and social problems are to be addressed.

An explicit valuation of EGS, however, was only carried out in the Davos case study region. Thus, cultural services are currently under-represented. Nevertheless, the framework and the model chain imply that economic valuation estimates of how much societal demand there will be for a particular service or good can be integrated easily. Non-use values of EGS, for example cultural services such as recreation, landscape amenity, and scenic beauty for tourism can be integrated using choice experiments based on three-dimensional simulations in the study areas (Daniel et al. 2012). This integration will be an integral part of a follow-up project.

Responses to this article can be read online at: http://www.ecologyandsociety.org/issues/responses. $\mathrm{php} / 5375$

\section{Acknowledgments:}

This work was supported by the CCES (Competence Centre Environment and Sustainability of the ETH Domain, Switzerland) as part of the MOUNTLAND project. We thank Silvia Dingwall and Jenny Bays for language corrections. Comments provided by an anonymous reviewer improved an earlier version of the manuscript.

\section{LITERATURE CITED}

Alberti, M., H. Asbjornsen, L. A. Baker, N. Brozovic, L. E. Drinkwater, S. A. Drzyzga, C. A. Jantz, J. Fragoso, D. S. Holland, T. A. Kohler, J. Liu, W. J. McConnell, H. D. G. Maschner, J. D. A. Millington, M. Monticino, G. Podestá, R. G. Pontius, Jr., C. L. Redman, N. J. Reo, D. Sailor, and G. Urquhart. 2011. Research on coupled human and natural systems (CHANS): approach, challenges, and strategies. Bulletin of the Ecological Society of America 92(2):218-228. http://dx.doi.org/10.1890/0012-9623-92.2.218

Balsiger, J. 2009. The impact of ecoregional mobilization on mountain policies in the Swiss Alps and California's Sierra Nevada. Revue de géographie alpine/Journal of Alpine Research 97-2. [online] URL: http://rga.revues.org/876. http://dx.doi.org/10.4000/rga.876

Beniston, M. 2003. Climatic change in mountain regions: a review of possible impacts. Climatic Change 59(1-2):5-31. http://dx.doi.org/10.1007/978-94-015-1252-7 2

Beniston, M. 2012. Impacts of climatic change on water and associated economic activities in the Swiss Alps. Journal of 
Hydrology 412-413:291-296. http://dx.doi.org/10.1016/j. jhydrol.2010.06.046

Boyd, J., and S. Banzhaf. 2007. What are ecosystem services? The need for standardized environmental accounting units. Ecological Economics 63(2-3):616-626. http://dx.doi. org/10.1016/j.ecolecon.2007.01.002

Braat, L. C., and R. de Groot. 2012. The ecosystem services agenda: bridging the worlds of natural science and economics, conservation and development, and public and private policy. Ecosystem Services 1(1):4-15. http://dx.doi.org/10.1016/j. ecoser.2012.07.011

Brand, F. S., R. Seidl, Q. B. Le, J. M. Brändle, and R. W. Scholz. 2013. Constructing consistent multiscale scenarios by transdisciplinary processes: the case of mountain regions facing global change. Ecology and Society 18(2): 43. http:// dx.doi.org/10.5751/ES-04972-180243

Brang, P. 2001. Resistance and elasticity: promising concepts for the management of protection forests in the European Alps. Forest Ecology and Management 145(1-2):107-119. http://dx. doi.org/10.1016/S0378-1127(00)00578-8

Briner, S., R. Huber, P. Bebi, C. Elkin, D. R. Schmatz, and A. Grêt-Regamey. 2013. Trade-offs between ecosystem services in a mountain region. Ecology and Society 18(3): 35. http:// dx.doi.org/10.5751/ES-05576-180335

Brunner, I., E. Graf Pannatier, B. Frey, A. Rigling, W. Landolt, S. Zimmermann, and M. Dobbertin. 2009. Morphological and physiological responses of Scots pine fine roots to water supply in a dry climatic region in Switzerland. Tree Physiology 29(4):541-550. http://dx.doi.org/10.1093/treephys/tpn046

Bugmann, H., A. B. Gurung, F. Ewert, W. Haeberli, A. Guisan, D. Fagre, A. Kääb, and GLOCHAMORE participants. 2007. Modeling the biophysical impacts of global change in mountain biosphere reserves. Mountain Research and Development 27(1):66-77. http://dx.doi.org/10.1659/0276-4741 (2007)27[66:MTBIOG]2.0.CO;2

Buttler, A., F. Kohler, and F. Gillet. 2009. The Swiss mountain wooded pastures: patterns and processes. Pages 377-396 in A. Rigueiro-Rodríguez, J. McAdam, and M. R. MosqueraLosada, editors. Agroforestry in Europe: current status and future prospects. Springer, New York, New York, USA. http:// dx.doi.org/10.1007/978-1-4020-8272-6 19

Carpenter, S. R., E. M. Bennett, and G. D. Peterson. 2006. Scenarios for ecosystem services: an overview. Ecology and Society 11(1): 29. [online] URL: http://www.ecologyandsociety. org/vol11/iss $1 /$ art29/.

Carpenter, S. R., H. A. Mooney, J. Agard, D. Capistrano, R. S. DeFries, S. Díaz, T. Dietz, A. K. Duraiappah, A. OtengYeboah, H. M. Pereira, C. Perrings, W. V. Reid, J. Sarukhan, R. J. Scholes, and A. Whyte. 2009. Science for managing ecosystem services: beyond the Millennium Ecosystem Assessment. Proceedings of the National Academy of Sciences 106(5):1305-1312. http://dx.doi.org/10.1073/pnas.0808772106

Cash, D. W., W. N. Adger, F. Berkes, P. Garden, L. Lebel, P. Olsson, L. Pritchard, and O. Young. 2006. Scale and crossscale dynamics: governance and information in a multilevel world. Ecology and Society 11(2): 8. [online] URL: http:// www.ecologyandsociety.org/vol11/iss2/art8/.

Chételat, J., M. Kalbermatten, K. S. M. Lannas, T. Spiegelberger, J. B. Wettstein, F. Gillet, A. Peringer, and A. Buttler. 2013. A contextual analysis of land-use and vegetation changes in two wooded pastures in the Swiss Jura Mountains. Ecology and Society 18(1): 39. http://dx.doi.org/10.5751/ ES-05287-180139

Claessens, L., J. M. Schoorl, P. H. Verburg, L. Geraedts, and A. Veldkamp. 2009. Modelling interactions and feedback mechanisms between land use change and landscape processes. Agriculture, Ecosystems and Environment 129 (1-3):157-170. http://dx.doi.org/10.1016/j.agee.2008.08.008

Costanza, R. 2008. Ecosystem services: multiple classification systems are needed. Biological Conservation 141(2):350-352. http://dx.doi.org/10.1016/j.biocon.2007.12.020

Daily, G. C., and P. A. Matson. 2008. Ecosystem services: from theory to implementation. Proceedings of the National Academy of Sciences 105(28):9455-9456. http://dx.doi. org/10.1073/pnas.0804960105

Daily, G. C., S. Polasky, J. Goldstein, P. M. Kareiva, H. A. Mooney, L. Pejchar, T. H. Ricketts, J. Salzman, and R. Shallenberger. 2009. Ecosystem services in decision making: time to deliver. Frontiers in Ecology and the Environment 7 (1):21-28. http://dx.doi.org/10.1890/080025

Dale, V. H., and S. Polasky. 2007. Measures of the effects of agricultural practices on ecosystem services. Ecological Economics 64(2):286-296. http://dx.doi.org/10.1016/j. ecolecon.2007.05.009

Daniel, T. C., A. Muhar, A. Arnberger, O. Aznar, J. W. Boyd, K. M. A. Chan, R. Costanza, T. Elmqvist, C. G. Flint, P. H. Gobster, A. Grêt-Regamey, R. Lave, S. Muhar, M. Penker, R. G. Ribe, T. Schauppenlehner, T. Sikor, I. Soloviy, M. Spierenburg, K. Taczanowska, J. Tam, and A. von der Dunk. 2012. Contributions of cultural services to the ecosystem services agenda. Proceedings of the National Academy of Sciences 109(23):8812-8819. http://dx.doi.org/10.1073/ pnas. 1114773109

de Groot, R. S., R. Alkemade, L. Braat, L. Hein, and L. Willemen. 2010. Challenges in integrating the concept of ecosystem services and values in landscape planning, management and decision making. Ecological Complexity 7 (3):260-272. http://dx.doi.org/10.1016/j.ecocom.2009.10.006 
Dobbertin, M., B. Eilmann, P. Bleuler, A. Giuggiola, E. Graf Pannatier, W. Landolt, P. Schleppi, and A. Rigling. 2010. Effect of irrigation on needle morphology, shoot and stem growth in a drought-exposed Pinus sylvestris forest. Tree Physiology 30(3):346-360. http://dx.doi.org/10.1093/treephys/ tpp123

Eilmann, B., and A. Rigling. 2012. Tree-growth analyses to estimate tree species' drought tolerance. Tree Physiology 32:(2)178-187. http://dx.doi.org/10.1093/treephys/tps004

Eilmann, B., R. Zweifel, N. Buchmann, P. Fonti, and A. Rigling. 2009. Drought-induced adaptation of the xylem in Scots pine and pubescent oak. Tree Physiology 29 (8):1011-1020. http://dx.doi.org/10.1093/treephys/tpp035

Elkin, C., B. Reineking, C. Bigler, and H. Bugmann. 2012. Do small-grain processes matter for landscape scale questions? Sensitivity of a forest landscape model to the formulation of tree growth rate. Landscape Ecology 27 (5):697-711. http://dx.doi.org/10.1007/s10980-012-9718-3

Eppink, F. V., A. Werntze, S. Mäs, A. Popp, and R. Seppelt. 2012. Land management and ecosystem services: how collaborative research programmes can support better policies. GAIA - Ecological Perspectives for Science and Society 21(1):55-63.

Fisher, B., and R. K. Turner. 2008. Ecosystem services: classification for valuation. Biological Conservation 141 (5):1167-1169. http://dx.doi.org/10.1016/j.biocon.2008.02.019

Flury, C., R. Huber, and E. Tasser. 2013. Future of mountain agriculture in the Alps. Pages 105-126 in S. Mann, editor. The future of mountain agriculture. Springer, Berlin, Germany. http://dx.doi.org/10.1007/978-3-642-33584-6 8

Folke, C. 2006. Resilience: the emergence of a perspective for social-ecological systems analyses. Global Environmental Change 16(3):253-267. http://dx.doi.org/10.1016/j.

gloenvcha.2006.04.002

Gavazov, K. S., A. Peringer, A. Buttler, F. Gillet, and T. Spiegelberger. 2013. Dynamics of forage production in pasture-woodlands of the Swiss Jura Mountains under projected climate change scenarios. Ecology and Society 18 (1): 38. http://dx.doi.org/10.5751/ES-04974-180138

Gillet, F. 2008. Modelling vegetation dynamics in heterogeneous pasture-woodland landscapes. Ecological Modelling 217(1-2):1-18. http://dx.doi.org/10.1016/j. ecolmodel.2008.05.013

Gómez-Baggethun, E., R. de Groot, P. L. Lomas, and C. Montes. 2010. The history of ecosystem services in economic theory and practice: from early notions to markets and payment schemes. Ecological Economics 69(6):1209-1218. http://dx. doi.org/10.1016/j.ecolecon.2009.11.007
Gonzalez, P., R. P. Neilson, J. M. Lenihan, and R. J. Drapek. 2010. Global patterns in the vulnerability of ecosystems to vegetation shifts due to climate change. Global Ecology and Biogeography 19(6):755-768. http://dx.doi.org/10.1111/ j.1466-8238.2010.00558.x

Gotsch, N., C. Flury, M. Kreuzer, P. Rieder, H. R. Heinimann, A. C. Mayer, and H.-R. Wettstein. 2004. Land- und Forstwirtschaft im Alpenraum - Zukunft im Wandel. Synthesebericht des Polyprojektes "PRIMALP - Nachhaltige Primärproduktion am Beispiel des Alpenraums". Vauk, Kiel, Germany.

Grêt-Regamey, A., P. Bebi, I. D. Bishop, and W. A. Schmid. 2008. Linking GIS-based models to value ecosystem services in an Alpine region. Journal of Environmental Management 89(3):197-208. http://dx.doi.org/10.1016/j.jenvman.2007.05.019

Grêt-Regamey, A., S. H. Brunner, J. Altwegg, M. Christen, and P. Bebi. 2013. Integrating expert knowledge into mapping ecosystem services trade-offs for sustainable forest management. Ecology and Society 18(3): 34. http://dx.doi. org/10.5751/ES-05800-180334

Haines-Young, R., and M. Potschin. 2009. Methodologies for defining and assessing ecosystem services. CEM report 14 for Joint Nature Conservation Committee project code C08-0170-0062. University of Nottingham, Nottingham, UK. [online] URL: http://www.nottingham.ac.uk/cem/pdf/ JNCC_Review_Final_051109.pdf.

Heal, G. M., and A. A. Small. 2002. Agriculture and ecosystem services. Pages 1341-1369 in B. L. Gardner and G. C. Rausser, editors. Handbook of agricultural economics: agriculture and its external linkages. Elsevier, Amsterdam, The Netherlands. http://dx.doi.org/10.1016/S1574-0072(02)10007-7

Hirschi, C. 2010. Strengthening regional cohesion: collaborative networks and sustainable development in Swiss rural areas. Ecology and Society 15(4): 16. [online] URL: http://www.ecologyandsociety.org/vol15/iss4/art16/.

Hirschi, C., A. Widmer, S. Briner, and R. Huber. 2013. Combining policy network and model-based scenario analyses: an assessment of future ecosystem goods and services in Swiss mountain regions. Ecology and Society 18 (2): 42. http://dx.doi.org/10.5751/ES-05480-180242 http:// dx.doi.org/10.5751/ES-05480-180242

Holling, C. S. 2001. Understanding the complexity of economic, ecological, and social systems. Ecosystems 4 (5):390-405. http://dx.doi.org/10.1007/s10021-001-0101-5

Huber, R., S. Briner, A. Peringer, S. Lauber, R. Seidl, A. Widmer, F. Gillet, A. Buttler, Q. Bao Le, and C. Hirschi. 2013. Modeling social-ecological feedback effects in the implementation of payments for environmental services in pasture-woodlands. Ecology and Society 18(2): 41. http://dx. doi.org/10.5751/ES-05487-180241 
Huber, R., A. Rigling, P. Bebi, F. S. Brand, S. Briner, A. Buttler, C. Elkin, F. Gillet, A. Grêt-Regamey, C. Hirschi, H. Lischke, R. W. Scholz, R. Seidl, T. Spiegelberger, A. Walz, W. Zimmermann, and H. Bugmann. 2013. Sustainable land use in mountain regions under global change: synthesis across scales and disciplines. Ecology and Society 18(3): 36. http:// dx.doi.org/10.5751/ES-05499-180336

Huber, U. M., H. K. M. Bugmann, and M. A. Reasoner, editors. 2005. Global change and mountain regions: an overview of current knowledge. Springer, Dordrecht, The Netherlands.

Ingold, K., J. Balsiger, and C. Hirschi. 2010. Climate change in mountain regions: how local communities adapt to extreme events. Local Environment 15(7):651-661. http://dx.doi. org/10.1080/13549839.2010.498811

Kok, K., and T. (A.) Veldkamp. 2011. Scale and governance: conceptual considerations and practical implications. Ecology and Society 16(2): 23. [online] URL: http://www. ecologyandsociety.org/vol16/iss2/art23/.

Kragt, M. E., L. T. H. Newham, J. Bennett, and A. J. Jakeman. 2011. An integrated approach to linking economic valuation and catchment modelling. Environmental Modelling and Software 26(1):92-102. http://dx.doi.org/10.1016/j. envsoft.2010.04.002

Lischke, H., N. E. Zimmermann, J. Bolliger, S. Rickebusch, and T. J. Löffler. 2006. TreeMig: a forest-landscape model for simulating spatio-temporal patterns from stand to landscape scale. Ecological Modelling 199(4):409-420. http://dx.doi. org/10.1016/j.ecolmodel.2005.11.046

Liu, J., T. Dietz, S. R. Carpenter, M. Alberti, C. Folke, E. Moran, A. N. Pell, P. Deadman, T. Kratz, J. Lubchenco, E. Ostrom, Z. Ouyang, W. Provencher, C. L. Redman, S. H. Schneider, and W. W. Taylor. 2007. Complexity of coupled human and natural systems. Science 317:1513-1516. http://dx. doi.org/10.1126/science.1144004

MacDonald, D., J. R. Crabtree, G. Wiesinger, T. Dax, N. Stamou, P. Fleury, J. Gutierrez Lazpita, and A. Gibon. 2000. Agricultural abandonment in mountain areas of Europe: environmental consequences and policy response. Journal of Environmental Management 59(1):47-69. http://dx.doi. org/10.1006/jema.1999.0335

Maes, J., B. Egoh, L. Willemen, C. Liquete, P. Vihervaara, J. P. Schägner, B. Grizzetti, E. G. Drakou, A. La Notte, G. Zulian, F. Bouraoui, M. L. Paracchini, L. Braat, and G. Bidoglio. 2012. Mapping ecosystem services for policy support and decision making in the European Union. Ecosystem Services 1 (1):31-39. http://dx.doi.org/10.1016/j.ecoser.2012.06.004

Martin, M., K. Gavazov, C. Körner, S. Hättenschwiler, and C. Rixen. 2010. Reduced early growing season freezing resistance in alpine treeline plants under elevated atmospheric
$\mathrm{CO}_{2}$. Global Change Biology 16(3):1057-1070. http://dx.doi. org/10.1111/j.1365-2486.2009.01987.x

Messerli, B., and J. D. Ives, editors. 1997. Mountains of the world: a global priority. Parthenon, New York, New York, USA.

Messerli, P., T. Scheurer, and H. Veit. 2011. Between longing and flight - migratory processes in mountain areas, particularly in the European Alps. Revue de géographie alpine/Journal of Alpine Research 99-1. [online] URL: http://rga.revues. org/1336. http://dx.doi.org/10.4000/rga.1336

Millennium Ecosystem Assessment. 2005. Ecosystems and human well-being: synthesis report. Island Press, Washington, D.C., USA.

Müller, F., and B. Burkhard. 2012. The indicator side of ecosystem services. Ecosystem Services 1(1):26-30. http://dx. doi.org/10.1016/j.ecoser.2012.06.001

Müller, F., R. de Groot, and L. Willemen. 2010. Ecosystem services at the landscape scale: the need for integrative approaches. Landscape Online 23:1-11. [online] URL: http:// www.landscapeonline.de/archive/2010/23/index.html.

Nelson, E., G. Mendoza, J. Regetz, S. Polasky, H. Tallis, D. R. Cameron, K. M. A. Chan, G. C. Daily, J. Goldstein, P. M. Kareiva, E. Lonsdorf, R. Naidoo, T. H. Ricketts, and M. R. Shaw. 2009. Modeling multiple ecosystem services, biodiversity conservation, commodity production, and tradeoffs at landscape scales. Frontiers in Ecology and the Environment 7(1):4-11. http://dx.doi.org/10.1890/080023

Ostrom, E. 2009. A general framework for analyzing sustainability of social-ecological systems. Science 325:419-422. http://dx.doi.org/10.1126/science.1172133

Peringer, A., S. Siehoff, J. Chételat, T. Spiegelberger, A. Buttler, and F. Gillet. 2013. Past and future landscape dynamics in pasture-woodlands of the Swiss Jura Mountains under climate change. Ecology and Society 18(3): 11. http:// dx.doi.org/10.5751/ES-05600-180311

Rigling, A., C. Bigler, B. Eilmann, E. Feldmeyer-Christe, U. Gimmi, C. Ginzler, U. Graf, P. Mayer, G. Vacchiano, P. Weber, T. Wohlgemuth, R. Zweifel, and M. Dobbertin. 2013a. Driving factors of a vegetation shift from Scots pine to pubescent oak in dry Alpine forests. Global Change Biology 9(1):229-240. http://dx.doi.org/10.1111/gcb.12038

Scholz, R. W., editor. 2011. Environmental literacy in science and society: from knowledge to decisions. Cambridge University Press, Cambridge, UK. http://dx.doi.org/10.1017/ CBO9780511921520

Scholz, R. W., and F. Brand. 2011. Comparing the HES framework with alternative appraoches. Pages 509-523 in R. W. Scholz, editor. Environmental literacy in science and 
society: from knowledge to decisions. Cambridge University Press, Cambridge, UK.

Scholz, R. W., and O. Tietje. 2002. Embedded case study methods: integrating quantitative and qualitative knowledge. Sage, Thousand Oaks, California, USA.

Schröter, D., W. Cramer, R. Leemans, I. C. Prentice, M. B. Araújo, N. W. Arnell, A. Bondeau, H. Bugmann, T. R. Carter, C. A. Gracia, A. C. de la Vega-Leinert, M. Erhard, F. Ewert, M. Glendining, J. I. House, S. Kankaanpää, R. J. T. Klein, S. Lavorel, M. Lindner, M. J. Metzger, J. Meyer, T. D. Mitchell, I. Reginster, M. Rounsevell, S. Sabaté, S. Sitch, B. Smith, J. Smith, P. Smith, M. T. Sykes, K. Thonicke, W. Thuiller, G. Tuck, S. Zaehle, and B. Zierl. 2005. Ecosystem service supply and vulnerability to global change in Europe. Science 310:1333-1337. http://dx.doi.org/10.1126/science.1115233

Schumacher, S., H. Bugmann, and D. J. Mladenoff. 2004. Improving the formulation of tree growth and succession in a spatially explicit landscape model. Ecological Modelling 180 (1):175-194. http://dx.doi.org/10.1016/j.ecolmodel.2003.12.055

Seppelt, R., C. F. Dormann, F. V. Eppink, S. Lautenbach, and S. Schmidt. 2011. A quantitative review of ecosystem service studies: approaches, shortcomings and the road ahead. Journal of Applied Ecology 48(3):630-636. http://dx.doi.org/10.1111/ j.1365-2664.2010.01952.x

Smith, P., D. Martino, Z. Cai, D. Gwary, H. Janzen, P. Kumar, B. McCarl, S. Ogle, F. O'Mara, C. Rice, B. Scholes, O. Sirotenko, M. Howden, T. McAllister, G. Pan, V. Romanenkov, U. Schneider, S. Towprayoon, M. Wattenbach, and J. Smith. 2008. Greenhouse gas mitigation in agriculture. Philosophical Transactions of the Royal Society B: Biological Sciences 363(1492):789-813. http://dx.doi.org/10.1098/rstb.2007.2184

Soliva, R. 2007. Agricultural decline, landscape change, and outmigration. Mountain Research and Development 27 (2):124-129. http://dx.doi.org/10.1659/mrd.0907

Spehn, E. M., K. Rudmann-Maurer, C. Körner, and D. Maselli, editors. 2010. Mountain biodiversity and global change. GMBA-DIVERSITAS, Basel, Switzerland. [online] URL: http://gmba.unibas.ch/publications/pdf/Mountain Biodiversity Brochure2010.pdf.

Steffen, W. 2009. Interdisciplinary research for managing ecosystem services. Proceedings of the National Academy of Sciences 106(5):1301-1302. http://dx.doi.org/10.1073/ pnas.0812580106

Streifeneder, T., U. Tappeiner, F. V. Ruffini, G. Tappeiner, and C. Hoffmann. 2007. Selected aspects of agro-structural change within the Alps: a comparison of harmonised agrostructural indicators on a municipal level in the Alpine Convention area. Revue de géographie alpine/Journal of
Alpine Research 95-3:41-52. [online] URL: http://rga.revues. org/295. http://dx.doi.org/10.4000/rga.295

Tress, B., G. Tress, H. Décamps, and A.-M. d'Hauteserre. 2001. Bridging human and natural sciences in landscape research. Landscape and Urban Planning 57(3-4):137-141. http://dx.doi.org/10.1016/S0169-2046(01)00199-2

Tress, B. R., G. Tress, and G. Fry. 2005. Researchers' experiences, positive and negative, in integrative landscape projects. Environmental Management 36(6):792-807. http:// dx.doi.org/10.1007/s00267-005-0038-0

Tress, G., B. R. Tress, and G. Fry. 2007. Analysis of the barriers to integration in landscape research projects. Land Use Policy 24(2):374-385. http://dx.doi.org/10.1016/j. landusepol.2006.05.001

Wallace, K. J. 2007. Classification of ecosystem services: problems and solutions. Biological Conservation 139 (3-4):235-246. http://dx.doi.org/10.1016/j.biocon.2007.07.015

Zimmermann, P., E. Tasser, G. Leitinger, and U. Tappeiner. 2010. Effects of land-use and land-cover pattern on landscapescale biodiversity in the European Alps. Agriculture, Ecosystems and Environment 139(1-2):13-22. http://dx.doi. org/10.1016/j.agee.2010.06.010 